\title{
Changes in the Urban Structure of Joetsu City after Municipal Amalgamation
}

\author{
KATAYANAGI Tsutomu \\ Faculty of Geo-environmental Science, Rissho University, Kumagaya 360-0194, Japan
}

\begin{abstract}
Amalgamations of cities in Japan have increased since the 1960s. Aiming at regional development in accordance with the progress of industrialization and urbanization, this process has created many new cities which have more than one "central" built-up area. These cities have had to face such problems as the areal distribution of public investment and the formation of new urban structures, yet before these problems can be considered, it is necessary to examine the changes in their urban structures. This paper does so for the city of Joetsu, which was amalgamated from the cities of Takada and Naoetsu, of similar size, in 1971. After amalgamation, the municipal government devised a plan to urbanize the built-up areas between Takada and Naoetsu. In the early 1970s, new administrative and cultural facilities were constructed in the Kida area close to Kasugayama Station, and since the 1980s many public facilities and large-scale retail stores have been built or located in the Sekikawa-Toubu area. Joetsu now has administrative and cultural centers in the Kida and Sekikawa-Toubu areas, as well as in the built-up areas of the former cities of Takada and Naoetsu. It can be said that the urban structure of Joetsu has become spatially dispersed because of the equal amalgamation of the two cities.
\end{abstract}

Key words: municipal amalgamation, Joetsu city, local government, city planning, public facilities

\section{Introduction}

In Japan there are many municipalities which have more than one built-up area within their administrative boundaries. This kind of city has become more common after the Law for Promoting the Amalgamation of Towns and Villages came into effect in 1953, and many cities with a multi-centered urban structure appeared in the 1960s after the Exemption Law about Amalgamating Cities was enacted in 1962. The city of Kitakyushu was formed by amalgamating five cities, and Oita City amalgamated with the adjacent city of Tsurusaki after the second law was passed. In 1966, the city of Iwaki was created through an amalgamation of five cities, four towns, and five villages under the Law for Constructing New Industrial Cities. Many amalgamations subsequently took place throughout the country, but the movement toward amalgamation stagnated in the late 1970 s and the 1980 s before being revived in the early 1990s.

In 1991 the Provincial Council on Adminis- trative and Fiscal Reform declared that more administrative powers needed to be given to local governments in order to reduce their overconcentration in Tokyo. The council created a plan to reorganize about 3,300 municipalities into 300 or 500 , which has led to many plans for municipal amalgamation focusing on a core city. An important reason for the recent movement toward municipal amalgamation is that living space and economic spheres have spread across the boundaries of traditional municipalities.

The amalgamation of cities causes various problems for a local government that has to develop a city. Among these are issues pertaining to the distribution of public investment monies and the effective conversion of urban space. Since amalgamations of cities are likely to continue in the future, it is useful to examine the spatial change in urban structures after amalgamation.

This paper therefore looks into such spatial change in the city of Joetsu, in the western part of Niigata Prefecture, by analyzing the trend in its city planning and the distribution of public 
facilities there. Some administrative documents, such as those related to amalgamation, and public relations magazines were examined because the local government must play an important role in implementing development plans after amalgamation.

Joetsu was created through the amalgamation of the previous cities of Takada and Naoetsu which had had different economic bases (Figure 1). According to a study conducted by the author, Joetsu is a "remote combination type" municipality which has at least two physically separated centrally built-up areas within its boundary. ${ }^{1}$ Because thirty years have passed since amalgamation and the transportation network and socioeconomic environment around the city have changed greatly, the author felt that Joetsu would be a suitable example for a study on the transformation of urban structure after amalgamation.

There have been many geographical studies about municipal amalgamation and urban structure. Fujioka (1961) classified the municipalities which amalgamated immediately after the enactment of the Law for Promoting the Amalgamation of Towns and Villages into twelve types. He showed that municipalities with more than one core area were created, and later made it clear that the cities created through municipal amalgamation had two or more core areas which were historically different (Fujioka 1977). These analyzed the actual situation of amalgamated cities, but he did not mention the process of changing urban structure after amalgamation. Yokoo (1995) described such a process in his study on the city of Hachinohe, which amalgamated before World War II and integrated five historical centrally built-up areas.

In regard to public administration and public finance, there are a large number of studies concerned with municipal amalgamation. Some of these investigated the city of Iwaki, where the relationship between the administrative office and residents had weakened after amalgamation (Toki 1978). Shindou (1978) focused on the changes in administrative organization, and he noted that the movement to integrate the merged city had accelerated the concentration of administrative offices in the gov-

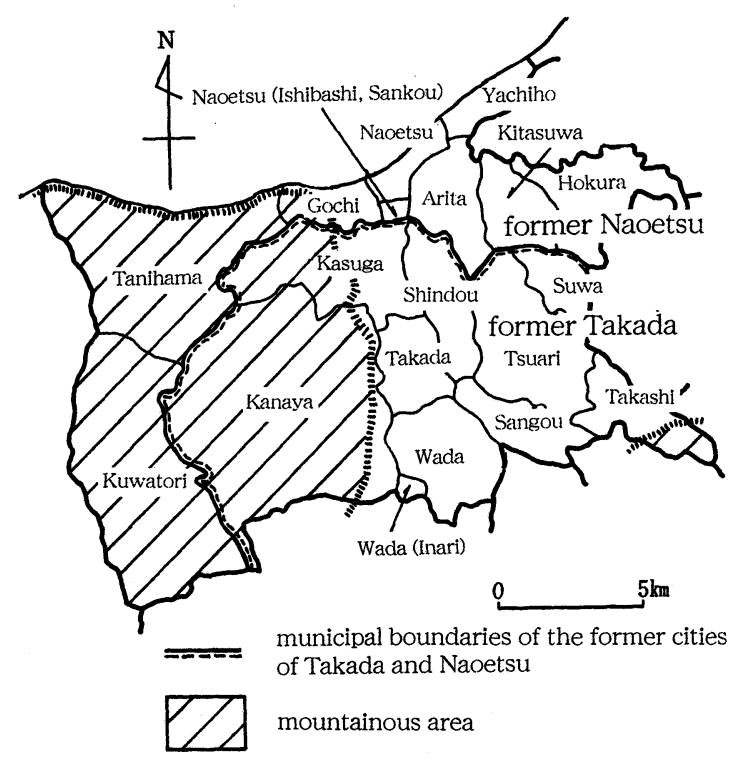

Figure 1. Study area.

Source: Niigata Prefectural Office (1962).

ernmental district at Taira. Fukutake et al. (1958) pointed out that public investment after amalgamation was concentrated in the former town of Washizu which had become the center of Kosei town in Shizuoka prefecture. Such studies discussed the relationship between local residents and the local government, and also addressed the efficiency of administration and the distribution of public investment. They did not, however, mention the spatial change of cities after amalgamation.

\section{Municipal Amalgamation and a New Municipal Development Plan}

In the Joetsu district, there were two proposed attempts to amalgamate for creating a core city before World War II. The first, proposed by Ibaraki Kazuhisa in 1934, was to amalgamate the city of Takada and the town of Naoetsu, and the second was an amalgamation plan by Takada in 1940 that aimed to make a large-scale city. Because Naoetsu did not agree to these plans, nothing happened until the Law for Promoting the Amalgamation of Towns and Villages came into effect, when Takada, Naoetsu, and the town of Arai enlarged their areas by annexing neighboring towns and villages under the law (Council for Amalgamation of the 
Cities of Takada and Naoetsu 1971).

The village of Kasuga was located between Takada and Naoetsu, both of which took an interest in the movement toward amalgamation of Kasuga. The Takashi and Kasuga areas in the southern part of the village depended on Takada socially and economically, while the Gochi area in the northern part of the village depended on Naoetsu. Takada insisted on annexing all of Kasuga, but Naoetsu wanted to incorporate the Gochi area which had already merged with the built-up area of Naoetsu (Niigata Prefectural Office 1962: 444). After the Council for Promoting Municipal Amalgamation in Niigata Prefecture determined that it was proper for Naoetsu to incorporate the Gochi area, the rest of the village of Kasuga was consolidated into Takada in February 1955 and in April the Gochi area was incorporated into Naoetsu, which had become a city in June 1954. Around this time, Takada and Naoetsu agreed to merge together in the near future.

The movement toward amalgamating Takada and Naoetsu proceeded rapidly, and based on the agreement of 1955, the Takada-Naoetsu Promotion Council was established in 1956. When the Ishibashi and Sankou areas of Kasuga were incorporated into Naoetsu in 1958, the agreement about amalgamating Takada and Naoetsu was reconfirmed and the Council for Promoting the Construction of the Joetsu Central City was established. It commissioned the Construction Plan for the Joetsu Regional City which was to comprise the cities of Takada, Naoetsu, and Arai as well as the villages of Oogata and Kubiki, and this plan envisaged a city of 170,000 to come into existence in April 1969 (Takada City Office 1967). It was assumed that Takada would join the amalgamation, but the participation of Naoetsu was not clear after it rejected the plan on the grounds that amalgamation would enhance the centrality of Takada. This defeated the amalgamation plan which included Arai (Joetsu City Office 1991: 295).

Subsequently, in November 1969, the Junior Chamber of Commerce of Takada-Naoetsu submitted a petition to the Takada and Naoetsu municipal assemblies about establishing a council for amalgamation that would resolve issues. Takada accepted the petition in March
1970, and Naoetsu did so in June. In August an extraordinary municipal assembly took place simultaneously in both cities, leading to the establishment of the Council for Municipal Amalgamation of Takada and Naoetsu, which began work in September. The municipal assemblies of Takada and Naoetsu resolved problems concerning amalgamation in January 1971 , and the city of Joetsu came into existence on April 29.

Ever since the first municipal amalgamation plan had been proposed in 1934, Naoetsu was always cautious about merging with Takada. Naoetsu wanted to amalgamate with Takada on equal terms, so it absorbed peripheral towns and villages to become an equal with Takada in administrative and financial power (Joetsu City Office 1991: 277). ${ }^{2}$ It can be said that this led to the division of Kasuga mentioned above.

In 1971, Naoetsu amalgamated with Takada on equal terms, and soon after, Route 18 (a national road) which linked the core areas of Takada and Naoetsu underwent urbanization. Since the core areas were seven kilometers apart, the municipal government of Joetsu had to decide whether to develop the two existing built-up areas at the same time or to build a new area to serve as an administrative center between them. Before the amalgamation of Takada and Naoetsu, the Takada-Naoetsu Regional City Plan was devised in 1965 by the City Planning Society and targeted the area to the west of Kasugayama Station to become the administrative and cultural center of the Joetsu district (City Planning Institute of Japan 1965). The New Municipal Development Plan was drafted in 1971, but it did not specify construction sites for public facilities, including a new city hall, and the areal distribution of public investment (Takada City Office and Naoetsu City Office 1971).

A specific blueprint for developing the city of Joetsu came shortly afterward. One of the reasons for convening the Joetsu municipal assembly in July 1971 was to reveal to the residents how the new city would be developed as well as a plan for the new city hall (Joetsu Municipal Assembly 1971), and in 1972 the area around Kasugayama Station was designated as a restricted zone. A basic policy of the plan was to 
Table 1. Population change by district in the city of Joetsu

\begin{tabular}{|c|c|c|c|c|c|}
\hline Name of district & $\begin{array}{c}\text { population } \\
1970\end{array}$ & $\begin{array}{c}\text { population } \\
1980\end{array}$ & $\begin{array}{c}\text { population } \\
1990\end{array}$ & $\begin{array}{c}\text { change } \\
1970-90\end{array}$ & $\begin{array}{c}\text { rate of change } \\
1970-90\end{array}$ \\
\hline Takada & 42,697 & 41,820 & 37,468 & $-5,299$ & $-12.2 \%$ \\
\hline Shindou & 4,700 & 6,548 & 7,333 & 2,633 & $56.0 \%$ \\
\hline Kanaya & 7,520 & 11,011 & 12,360 & 4,840 & $64.4 \%$ \\
\hline Suwa & 1,457 & 1,495 & 1,495 & 38 & $2.6 \%$ \\
\hline Wada & 5,080 & 5,200 & 5,596 & 516 & $10.2 \%$ \\
\hline Sangou & 1,562 & 1,373 & 1,342 & -220 & $-14.1 \%$ \\
\hline Tsuari & 5,162 & 4,654 & 4,772 & -390 & $-7.6 \%$ \\
\hline Kasuga & 4,497 & 8,937 & 13,599 & 9,102 & $202.4 \%$ \\
\hline Takashi & 2,378 & 2,169 & 2,009 & -369 & $-15.5 \%$ \\
\hline Former city of Takada & 75,053 & 83,207 & 85,974 & 10,921 & $14.6 \%$ \\
\hline Naoetsu & 17,197 & 13,577 & 10,767 & $-6,430$ & $-37.4 \%$ \\
\hline Arita & 8,738 & 10,399 & 11,516 & 2,778 & $31.8 \%$ \\
\hline Gochi & 6,024 & 8,376 & 9,588 & 3,564 & $59.2 \%$ \\
\hline Yachiho & 5,282 & 4,815 & 4,724 & -558 & $-10.6 \%$ \\
\hline Hokura & 2,875 & 2,773 & 2,801 & -74 & $-2.6 \%$ \\
\hline Kitasuwa & 1,659 & 1,589 & 1,901 & 242 & $14.6 \%$ \\
\hline Tanihama & 2,718 & 2,456 & 2,278 & -440 & $-16.2 \%$ \\
\hline Kuwatori & 864 & 650 & 567 & -297 & $-34.4 \%$ \\
\hline Former city of Naoetsu & 45,357 & 44,635 & 44,142 & $-1,215$ & $-2.7 \%$ \\
\hline Total & 120,410 & 127,842 & 130,116 & 9,706 & $8.1 \%$ \\
\hline
\end{tabular}

Note: The names of the districts are the same as those in Figure 1.

Source: population statistics of Joetsu for each year.

integrate the Takada and Naoetsu urban areas functionally and socially, and those projects which had been agreed upon before amalgamation were to be continued. Land readjustment projects along the peripheries of the existing built-up areas were also adopted (Joetsu City Office 1975, 1976).

\section{Changes in the Urban Areas after Amalgamation}

\section{Population and land use change}

Table 1 enumerates changes in population from 1970 to 1990 in the city of Joetsu. Remarkable decreases between 1970 and 1990 were experienced in the districts of Takada and Naoetsu, and there were decreases in the mountainous or agricultural districts of Sangou, Takashi, Yachiho, Tanihama, and Kuwatori. On the other hand, the population of the districts on the periphery of the previous two urban areas increased largely. Notably, the population of the Kasuga district located between the Takada and Naoetsu districts increased $202.4 \%$, and that of the Shindou, Kanaya, and Gochi districts increased more than 50\%.

Alongside the increase in population, land use between the two previous built-up areas has changed remarkably. Figure 2 shows that urbanization has progressed around Kasugayama Station during the last two decades, that some agricultural settlements have merged with the newly developed areas, that the Naoetsu built-up area has expanded remarkably to the south of the Hokuriku Main Line, and that the Takada built-up area has spread to the north and east. The main result is the conurbation of Takada and Naoetsu, which was greatly assisted by the City Hall of Joetsu, at first located jointly in the Takada and Naoetsu districts, being moved to one building to the east of Kasugayama Station in 1976. Also, the Takada branch of Niigata University was closed, and the newly established Joetsu University of Education was located about two kilometers to the southwest of Kasugayama Station. Judging from the population and land 

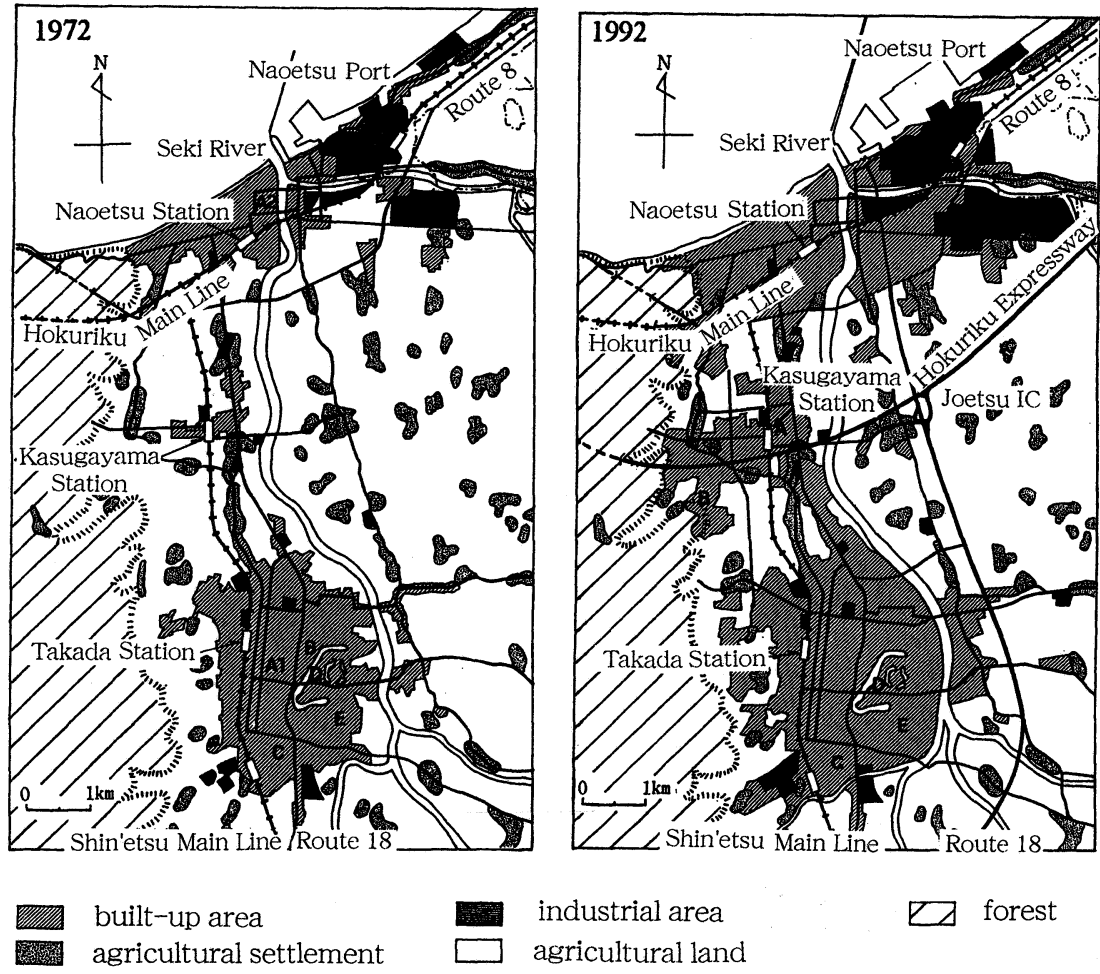

\section{industrial area}

agricultural land
A1 City Hall (Takada Annex)
A2 City Hall (Naoetsu Annex)
B Niigata University, Takada branch
C Takada National Hospital D Takada Park
E Ground Self-Defense Force, Takada garrison town

A City Hall B Joetsu University of Education

C Takada National Hospital D Takada Park

Figure 2. Urban land use in the city of Joetsu (1972, 1992).

Sources: topographical maps of Takada-Seibu, Takada-Toubu, and Naoetsu, and a field survey in 1995.

use changes in the city of Joetsu, it is clear that after amalgamation, priority was given to developing the area between the existing built-up areas of the north and south.

\section{Improvement of infrastructure and construc- tion of public facilities}

The designation of a restricted zone and the location of land readjustment projects reveal a trend in city planning and development in Joetsu. Before amalgamation, the urban areas of Takada and Naoetsu were designated as separate restricted zones, but there was not a plan to develop both urban areas as a unit at that time. Immediately after amalgamation in 1971, when the area around Kasugayama Station was designated as a restricted zone and the plan to construct a new city center was made public, there was still no intention to blend the existing urban areas physically. That happened after the restricted zone around Kasugayama Station spread toward Naoetsu (Figure 3).

Twenty eight land readjustment projects have been undertaken in the restricted zones of Joetsu. The projects to develop residential land around the built-up areas of Naoetsu and Takada that had begun before amalgamation continued, and the projects at Kasugayama, Sekikawa-Toubu, and Daigaku-Mae between the previously existing urban areas are currently in progress, as are those at Naoetsu-Ekinan, Takada-Ekimae, and Honchou-Oomachi within the previously built-up areas of Takada and Naoetsu and that at Koyasu-Kamojima along Route 18. Of the seven projects which are in progress now, the oldest was begun at Honchou- 


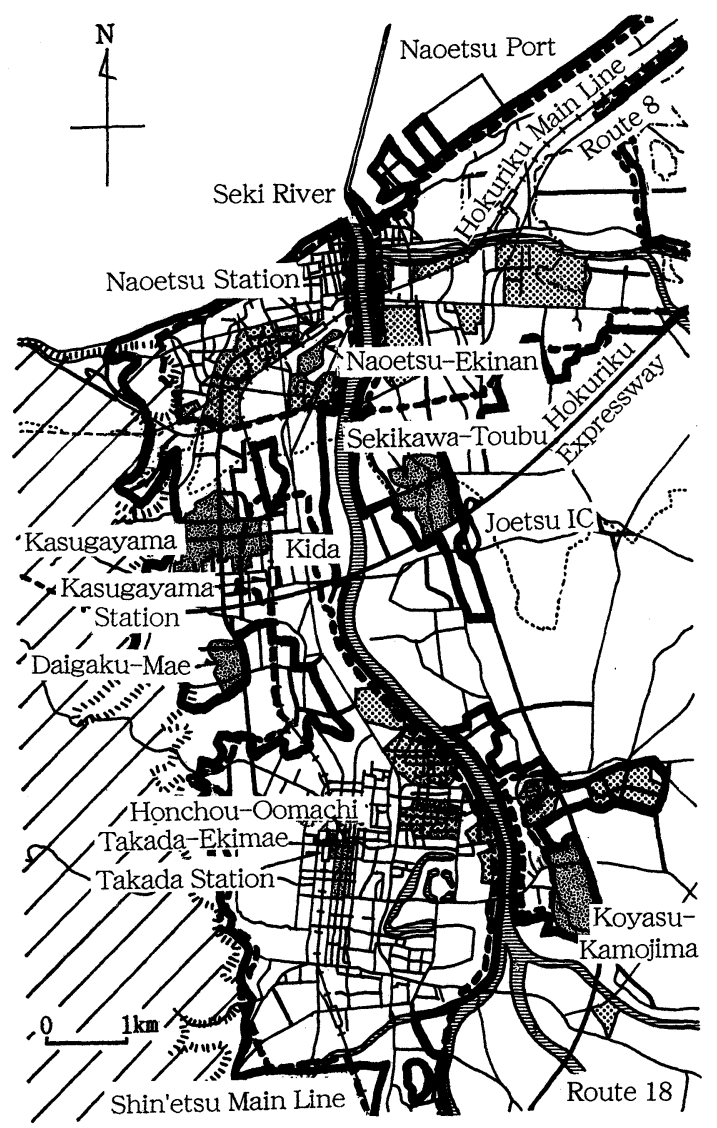

restricted zone
land readjustment
project

Figure 3. Development of land readjustments and extension of restricted zones in the city of Joetsu (1996).

Sources: topographical maps of TakadaSeibu, Takada-Toubu, and Naoetsu, city planning maps of Joetsu in 1972 and 1996, and a field survey in 1996.

Oomachi in 1978. Those at Kasugayama, Daigaku-Mae, and Koyasu-Kamojima are to develop residential land, while that at SekikawaToubu is designated to attract commercial facilities. These projects have been undertaken by a land readjustment association and started from the late $1980 \mathrm{~s}$, and the projects at Naoetsu-Ekinan and Takada-Ekimae were begun by the local government in the 1990s.

Public facilities are considered to be important in redeveloping old built-up areas and in
Table 2. Construction of the main public facilities in the city of Joetsu

\begin{tabular}{cc}
\hline Year & Name of public facilities \\
\hline 1971 A Cultural Center for Young People (Nao- \\
etsu)
\end{tabular}

1972 B Joetsu Municipal Museum (Takada)

1975 C Welfare Center for the Aged (Kasugayama)

1976 D Joetsu City Hall (Kida)

E All-Season Swimming Pool (Kida)

1978 F Joetsu Cultural Hall (Kida)

1979 G Gymnasium Complex (Kida)

H Gymnasium for the Working Handicapped (Kida)

1980 I Joetsu Municipal Aquarium (Naoetsu)

1982 J Health Center (Kida)

1984 K Region Plaza Joetsu (Sekikawa-Toubu)

L Joetsu Science Museum (Sekikawa-Toubu)

1989 M Civic Swimming Pool (Sekikawa-Toubu)

1990 N Rainbow Center (Naoetsu)

1991 O Social Insurance and Health Center (Takada)

P Joetsu Tourism and Local Products Center (Sekikawa-Toubu)

Q General Welfare Center (Kida)

1992 R Three-Storied Turret of Takada Castle (Takada)

S Former Division Commander's Official Residence (Takada)

$1994 \mathrm{~T}$ Takada Library (Takada)

U Naoetsu Float Museum (Naoetsu)

1995 V Japanese Ski Memorial Museum (Takada)

W Work Pal Joetsu (Sekikawa-Toubu)

$\mathrm{X}$ Gangidori Art Museum (Takada)

Note: $\mathrm{A}-\mathrm{X}$ correspond to $\mathrm{A}-\mathrm{X}$ in Figure 4, and the area where the public facility was constructed is given in parentheses.

Source: Joetsu City Office (1998).

developing new ones (Mitsuzaki 1991), so the author examined the location of the main public facilities which were built after amalgamation (Table 2, Figure 4). Immediately after amalgamation, the basic public facilities were located equally in Takada and Naoetsu, but in the 1970s such administrative and cultural facilities which served all of the residents of the city as the city hall, cultural hall, and gymnasium complex were built in the Kida area to the east of Kasugayama Station one after another. From the 1980s, public facilities were built intensively in the Sekikawa-Toubu area that was also designated to be an administrative and 


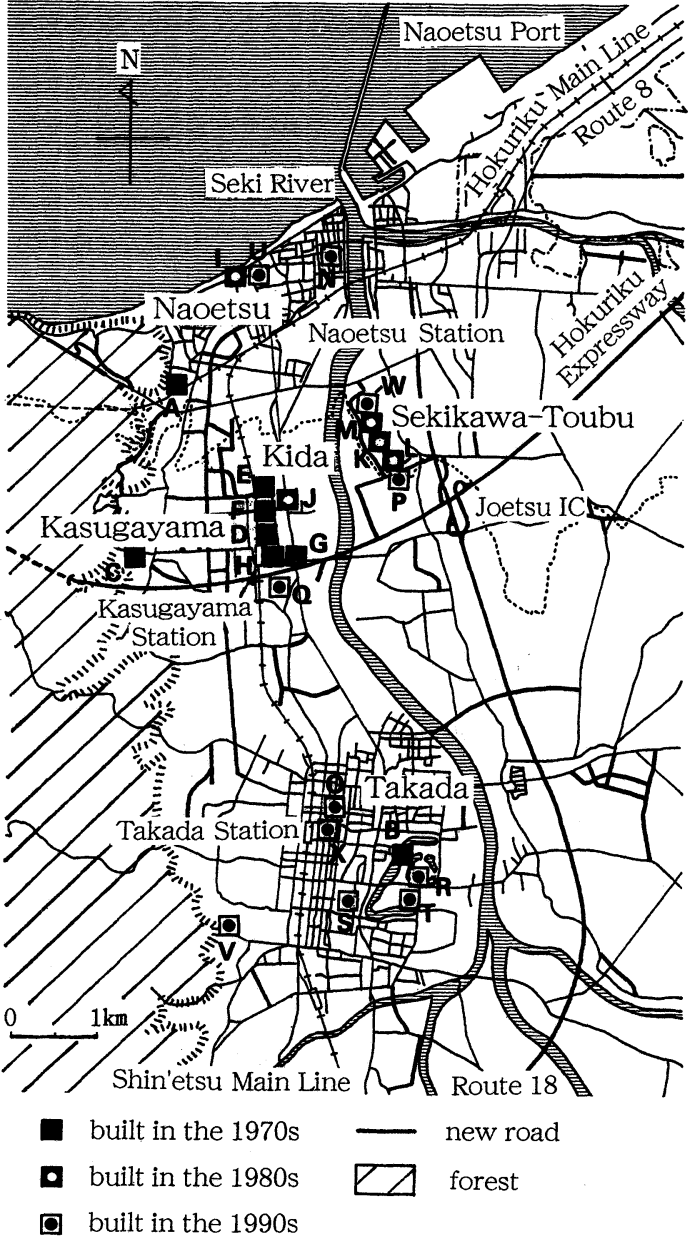

Figure 4. Location of the main public facilities built since amalgamation (as of 1996). Note: A-X correspond to A-X in Table 2. Source: Joetsu City Office (1998).

cultural center, and these included the Region Plaza Joetsu ( $\mathrm{K}$ in Figure 4) and the Joetsu Science Museum (L) which were built in 1984. The Civic Swimming Pool (M) and the Joetsu Tourism and Local Products Center $(\mathrm{P})$ were then built in succession. During the 1990s, tourist and cultural facilities such as the ThreeStoried Turret of Takada Castle (R), the Naoetsu Float Museum (U), the Japanese Ski Memorial Museum (V), and Takada Library $(\mathrm{T})$ were built within the two old urban areas.

The trend in city planning after amalgamation and the establishment of important public facilities clearly shows that the rural area between Takada and Naoetsu was intended to become a new administrative and cultural center that would serve as the nucleus around which other areas would be built up. Although sites for building public facilities have shifted from the Kida area to the Sekikawa-Toubu area, public facilities have been continuously built between the old urban areas of Takada and Naoetsu. On the contrary, there have been no land readjustment projects and construction of public facilities to the south of the Takada district. In this context, Joetsu is a typical example of an amalgamated city that respects the equality of the previous settlements by developing, where natural conditions permit, the area between them.

\section{Formation of new built-up areas}

Eliminating discord between the residents of Takada and Naoetsu was considered to be an important issue in Joetsu. This influenced the selection of a site for the new city hall, which was to function as a service center for all of the residents of the city. Although it was assumed that it need not be at the geometric center of the former cities of Takada and Naoetsu, the task force entrusted to the project limited its possible sites in September 1971 to Sakae 2-choume to the south of Naoetsu Station, and the Nakayashiki area to the west of Kasugayama Station. The regular municipal assembly in September did not, however, establish a site, but it did choose the Kida area to the east of Kasugayama Station in December. The reason for this decision was that the Kida area was conveniently accessed from the station and Route 18, as well as being located between Takada and Naoetsu, hence it was considered suitable for further development as a new residential area and as an administrative center (Joetsu Municipal Assembly 1972a). Kida was subsequently designated as a restricted zone by the municipal assembly in June 1972, and the local government established the Land Development Public Corporation to begin development. It also purchased 41,961 square meters of rice fields to the north of the site for the new city hall which has since been developed. The opinion that a site between the previously existing cities was the most suitable for the new city hall was accepted among the local resi- 


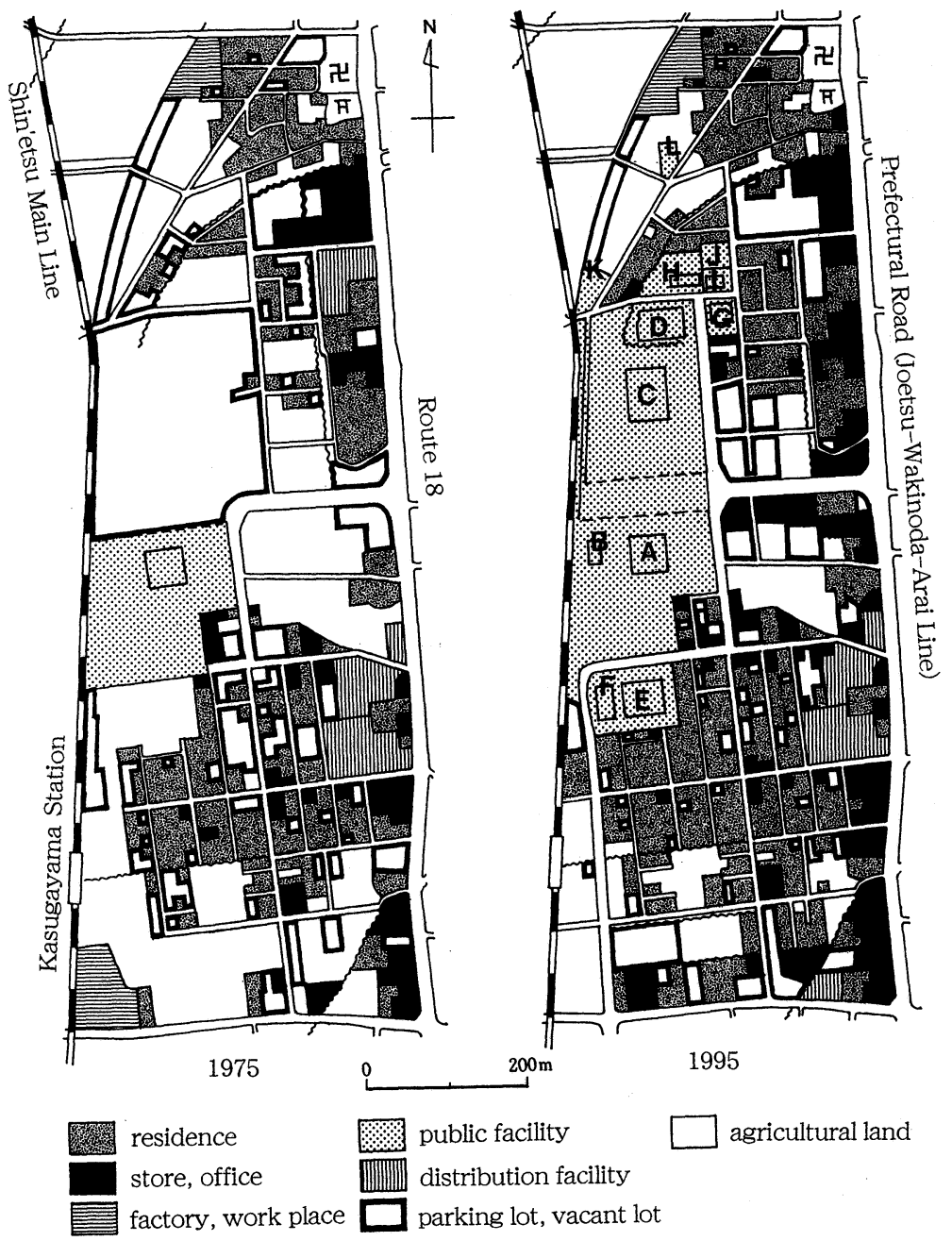

$\begin{array}{ll}\text { A Joetsu City Hall } & \text { B Joetsu City Gas and Water Utilities Bureau } \\ \text { C Joetsu Cultural Hall } & \text { D All-Season Swimming Pool } \\ \text { E Gymnasium Complex } & \text { F Gymnasium for the Working Handicapped } \\ \text { G Health Center } & \text { H Joetsu Chamber of Commerce } \\ \text { I Holiday Dental Examination Center } & \text { J Oomagari Kindergarten } \\ \text { K Joetsu Forest Association } & \text { L Joetsu Plumbing Construction Hall }\end{array}$

Figure 5. Land use change in the Kida area.

Sources: the residential atlas of Joetsu, an aerial photograph of the Kida area in 1975, the yellow pages of the local telephone directory, and a field survey in 1995 .

dents (Joetsu Municipal Assembly 1972b), while complaints among the residents to the south of Takada have grown as development between Takada and Naoetsu takes place.

Figure 5 shows how land was used in the Kida area in 1975 and 1995. Soon after amalgamation, there were many parking lots and vacant lots. Some commercial facilities already existed along Route 18 , and the number of resi- dences had increased to the east of Kasugayama Station. The vacant land to the north of the site for the new city hall had been purchased to build more administrative and cultural facilities.

In the late 1970s and the early 1980s, public facilities were built in succession, and by 1995 the main public facilities were concentrated along the Shin'etsu Main Line. Close to the new 
city hall, the Joetsu branch of Niigata Nippou (a daily newspaper publishing company) and the Kasugayama branch of the Niigata-ken Credit Union have been opened, while some retail stores, service offices, other kinds of offices, and two business hotels have been opened along the prefectural road (Joetsu-Wakinoda-Arai Line). ${ }^{3}$ Although new public facilities have not been built in the latter half of the 1990s and there are many parking lots and vacant lots, it is clear that land which was formerly devoted to agriculture has been converted to urban uses. Because there was insufficient space to build another large facility in Kida, the SekikawaToubu area near the Joetsu Interchange, which was opened in 1988, has been selected for new development. In conjunction with Kida being developed as an administrative and cultural center, the area of Kasugayama to the west of Kasugayama Station has undergone residential development since 1987. This was given priority because of its location between Takada and Naoetsu.

Starting with the Region Plaza Joetsu in 1984, public facilities were constructed in the Sekikawa-Toubu area in the 1980s. Located between Takada and Naoetsu along the eastern bank of the Seki River, this area also has reasonably good access from Routes 8 and 18 (see Figure 3). The Joetsu Wing Market Center, covering an area of 149,984 square meters, opened to the south of the Joetsu Interchange in 1994, while a land readjustment project to the north of the interchange has been underway since 1993. The Joetsu Shopping Center which opened there in March 1996 is a large-scale suburban shopping center covering 50,868 square meters with 80 specialty stores and an outlet of the large retail chain Jusco. The total counter area of these two shopping centers is about 70,000 square meters, 1.5 times that of all the commercial space in Takada and three times that in Naoetsu. Around the interchange, many large-scale retail stores have been opened or are planned to open in what will be a new commercial area with two existing shopping centers (Figure 6), however this has less to do with municipal amalgamation than with the opening of the Hokuriku Expressway and Joetsu Interchange.
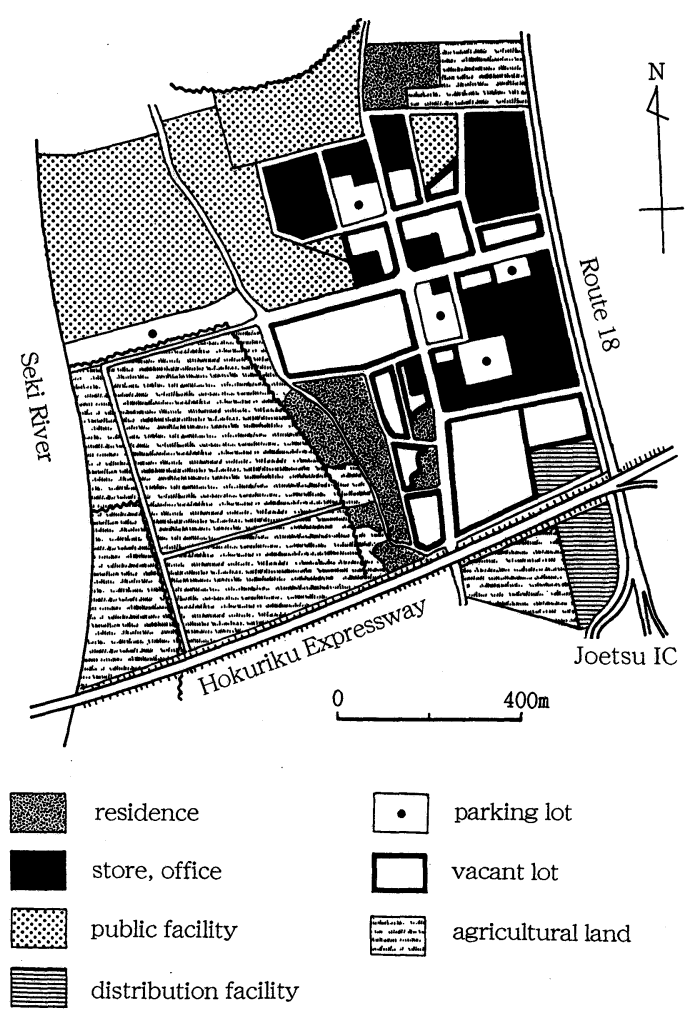

Figure 6. Land use in the Sekikawa-Toubu area (1996).

Source: a field survey in 1996.

\section{Conclusions}

Spatial change in the urban structure of the city of Joetsu after it was amalgamated has been discussed in this paper. Based on literary and cartographic sources and on a field survey, the following conclusions have been reached.

The cities of Takada and Naoetsu each had a historical core area, and they amalgamated on equal terms. To develop the new city, the local government needed either to redevelop the two existing built-up areas at the same time or to build a new administrative center between them. After the latter was decided upon, a development plan that aimed to urbanize the area between Takada and Naoetsu was drafted.

The area around Kasugayama Station and the Sekikawa-Toubu area, both of which are between the previously existing built-up areas, were given priority for development. In the early 1970s, important public facilities were 
built in the Kida area to the east of Kasugayama Station, while many public facilities have been built in Sekikawa-Toubu since the 1980s and large-scale retail stores have located there in the 1990s. Besides such development, some land in the Kasugayama area has been developed since the late 1980 s for residential purposes.

At present, therefore, the city of Joetsu has new administrative, cultural centers in the Kida and Sekikawa-Toubu areas, as well as the previously existing core areas of Takada and Naoetsu. After amalgamation, Joetsu has come to have four core areas, so it can be said that amalgamation by the two cities on equal terms has promoted spatial dispersion in the urban structure.

Editor's Note: This article was first published in Japanese in the Geographical Review of Japan 70A, 577-588, 1997.

\section{Notes}

1. The author selected municipalities from all over Japan which were created by amalgamating more than one city. Municipalities were classified into four types according to their total population, the population scale of their densely inhabited districts (DIDs), and the distribution of their DIDs: proximate annexation, proximate combination, remote annexation, and remote combination. In 1970 Takada had a population that was 1.7 times greater than that of Naoetsu, and the population scale of the DIDs for both cities had a ratio of $2: 1$.

2. In 1969, two years before amalgamation, the annual revenue of Takada was 2,396 million yen and that of Naoetsu was 1,438 million yen, and their municipal tax revenues were almost the same, 877 million yen and 873 million yen respectively; the financial index of Naoetsu was 1.09 and that of Takada was 0.64 . Naoetsu was the only municipality in Niigata prefecture which did not receive a financial grant from the national government.

3. When the new national road Route 18 opened in 1991 , old Route 18 became a prefectural road and was renamed the Joetsu-Wakinoda-Arai Line.

\section{References}

City Planning Institute of Japan. ed. 1965. Niigata-ken Takada-Naoetsu chiiki kouiki toshikeikaku (Re- gional city planning in the Takada-Naoetsu area, Niigata prefecture). (J)

Council for Amalgamation of the Cities of Takada and Naoetsu. 1971. Gappei Kyougikai dayori daiyongou (News of the Council for Amalgamation, No. 4, February 5). (J)

Fujioka K. 1961. Shakaiteki chiikikagaku toshite no chirigaku (Geography as a social and regional science). Tokyo: Taimeidou. (J)

Fujioka K. 1977. Gendai toshi no rekishichirigakuteki bunseki (Analysis of the historical geography of modern cities). Tokyo: Kokon-shoin. (J)

Fukutake T. et al. eds. 1958. Gappei shichouson no jittai (The actual situation of a consolidated municipality). Tokyo: University of Tokyo Press. (J)

Joetsu City Office. 1975. Kouhou Joetsu (Public relations magazine Joetsu, November 15). (J)

Joetsu City Office. 1976. Kouhou Joetsu (Public relations magazine Joetsu, August 15). (J)

Joetsu City Office. 1991. History of Joetsu city. (J)

Joetsu City Office. 1998. Joetsu-shi shisei youran (Handbook of the demographic, social, and economic conditions in the city of Joetsu). (J)

Joetsu Municipal Assembly. 1971. Joetsu Shigikai rokugatsu teireikai teian riyu (The reason for convening the regular municipal assembly in June). (J)

Joetsu Municipal Assembly. 1972a. Joetsu Shigikai dayori (Joetsu Municipal Assembly news, February 15). (J)

Joetsu Municipal Assembly. 1972b. Joetsu Shigikai dayori (Joetsu Municipal Assembly news, November 1). (J)

Mitsuzaki Y. 1991. Toshikeikaku, kaiteiban (City planning, revised edition). Tokyo: Kajima Institute Publishing. (J)

Niigata Prefectural Office. 1962. Niigata-ken shichouson gappeishi, gekan (Municipal amalgamation magazine, Niigata prefecture, vol. 2). (J)

Shindou M. 1978. Gyouseisoshiki no hen'you to tokushitsu (Transfiguration of an administrative organization and its character). Toshi Mondai (Municipal problems) 69(6): 11-36. (J)

Takada City Office. 1967. Kouhou Takada (Public relations magazine Takada, January 15). (J)

Takada City Office and Naoetsu City Office. 1971. Shi no haichibungou ni kansuru shinseisho (Application for the arrangement, division, and integration of the cities of Takada and Naoetsu). (J)

Toki H. 1978. Kouikigappei to juumin (Regional amalgamation and residents). Toshi Mondai (Municipal problems) 69(6): 5-10. (J)

Yokoo M. 1995. Changes in the land use pattern of Hachinohe before its industrialization. Quarterly Journal of Geography 47: 119-134. (JE)

$(\mathrm{J})$ : written in Japanese

(JE): written in Japanese with English abstract 